Haya: The Saudi Journal of Life Sciences

Abbreviated Key Title: Haya Saudi J Life Sci

ISSN 2415-623X (Print) |ISSN 2415-6221 (Online)

Scholars Middle East Publishers, Dubai, United Arab Emirates

Journal homepage: https://saudijournals.com

Original Research Article

\title{
Compatibility, Phosphate Solubility and Phosphatase Activity by Phosphate Solubilizing Bacteria
}

\author{
Betty Natalie Fitriatin $^{1 *}$, Dahlia Florencia Manurung ${ }^{2}$, Emma Trinurani Sofyan ${ }^{1}$, Mieke Rochimi Setiawati ${ }^{1}$ \\ ${ }^{1}$ Department of Soil Sciences and Land Resouces Management, Agriculture Faculty, Universitas Padjadjaran - Jatinangor 45363-West Java, Indonesia \\ ${ }^{2}$ Agrotechnology, Agriculture Faculty, Universitas Padjadjaran-Jatinangor 45363-West Java, Indonesia
}

DOI: $10.36348 /$ sjls.2020.v05i12.003

| Received: 21.11.2020 | Accepted: 03.12.2020 | Published: 07.12.2020

*Corresponding author: Betty Natalie Fitriatin

\section{Abstract}

The phosphate solubilizing bacteria are soil microbe can dissolve $\mathrm{P}$ which is not available to become available to plants. They have capable to produce extracelluler enzyme, i.e. group of phosphatase enzyme which able to mineralized of organic P to inorganic P. The objective of this experiment was to examine compatibility test, phosphatase enzyme activity and phosphate solubility by phosphate solubilizing bacteria. The compatibility test was conducted qualitatively with the streak method. The design for bioassay of phosphate solubilizing phosphate for phosphatase activity test and $\mathrm{P}$ solubility was a randomized block design with five treatments and five replications. The phosphate solubilizing bacteria used were Burkolderia sp., Pseudomonas mallei, Bacillus substilis, and Bacillus megatherium. The results of the compatibility test on the phosphate solubilizing bacterial isolates showed that each isolate was compatible. Furthermore, the result of experiment revealed that phosphate solubilizing bacteria could produce phosphatase enzyme ranges between 4,53-4,82 $\mu \mathrm{g} \mathrm{pNP/g/h}$ and P dissolved about 3909,55-6052,19 ppm. These phosphate solubilizing bacteria can be used as biofertilizers to increase soil $\mathrm{P}$ solubility.

Keywords: Biofertilizers, enzyme, P dissolved, soil microbe.

Copyright (C) 2020 The Author(s): This is an open-access article distributed under the terms of the Creative Commons Attribution 4.0 International License (CC BY-NC 4.0) which permits unrestricted use, distribution, and reproduction in any medium for non-commercial use provided the original author and source are credited.

\section{INTRODUCTION}

Phosphate solubilizing bacteria can help make $\mathrm{P}$ available in the soil to be absorbed by plants. The ability of phosphate solubilizing microorganisms will vary depending on the type of microbe, adaptability, to the ability to produce enzymes and organic acids [1]. One of the microorganisms that can be used to help provide $\mathrm{P}$ in the soil is to use phosphate solubilizing bacteria. $\mathrm{P}$ that is not dissolved in the soil will be converted by various mechanics so that it becomes dissolved $\mathrm{P}$ that can be absorbed by plants.

Phosphate solubilizing bacteria produce organic acids, hydroxyl and carboxyl groups. Organic acids and their functional groups chelate the cation bound to the phosphate so that the group that binds $\mathrm{P}$ can break off and change to a soluble form [2, 3]. In addition, phosphate solubilizing microorganisms can mineralize organic phosphate to inorganic phosphate in the presence of phosphatase enzyme activity [4]. Phosphate solubilizing microbes can also play a role in energy transfer, preparation of proteins, coenzymes, nucleic acids, and other metabolic compounds that can increase $\mathrm{P}$ absorption activity in plants that are deficient in $\mathrm{P}$ [5].

The main phosphate dissolving mechanism by phosphate solubilizing microbes is to use organic acids. Some of the organic acids produced by phosphate solubilizing microbes include formic acid, gluconic acid, oxalate, citric, lactic, 2-ketoglyconic, succinic, isovalerate, acetic acid, etc. which can lower the $\mathrm{pH}$ in the surrounding environment [6]. Organic acids are produced from strains of bacteria and fungi that can dissolve high amounts of phosphate minerals by supplying protons and metal complexes of organic acid anions [7].

Previously, there have been many studies on the positive correlation between the decrease in $\mathrm{pH}$ and the concentration of $\mathrm{P}$ dissolved in the medium [8]. This indicates a correlation between the activity of organic acids produced by phosphate solvent microbes and the concentration of dissolved $\mathrm{P}$ because the production of organic acids is usually followed by a decrease in $\mathrm{pH}$. Organic acid will chelate the $\mathrm{Ca}, \mathrm{Fe}$ and $\mathrm{Al}$ cations which are bound to the phosphate via 
hydroxyl and carboxyl groups then convert $\mathrm{P}$ into a soluble form available for absorption by plants $[5,9]$.

The synergism mechanism between isolates in the consortium is still not known with certainty, but several studies suspect it is due to several factors, including: (1) one member of the genus is able to provide one or more nutritional factors that cannot be synthesized by other members of the genus, (2) one member of the genus that is unable to degrade certain organic matter will depend on a member of the genus that is able to provide the results of the degradation of the organic toxic by producing specific and non-specific protective factors [10]. The purpose of this study is to determine the compatibility between phosphate solubilizing bacteria and the activity of the enzyme phosphatase produced and the ability to dissolve soil phosphorus.

\section{MATERIAL AND METHOD}

The experiment was carried out from August to September 2020 at the Soil Biology Laboratory of the Department of Soil and Land Resources, Faculty of Agriculture, Universitas Padjadjaran, Indonesia. The materials used in this experiment were 4 isolates of phosphate solubilizing bacteria, namely Burkolderia sp., Pseudomonas mallei, Bacillus substilis and Bacillus megatherium which are collections from the Soil Biology Laboratory isolated from various rhizosphere of food and vegetable plants. The compatability test used nutrient agar, while the bioassay used modified Murphy media.

The compatibility test was conducted qualitatively with the streak method. The design for bioassay of phosphate solubilizing phosphate for phosphatase activity test and $\mathrm{P}$ solubility was a randomized block design with five treatments and five replications. The treatments were control, isolate of Burkolderia sp., Pseudomonas mallei, Bacillus substilis, Bacillus megatherium and mixed of isolates.

The compatibility test with the scratch method uses nutrient agar. Each isolate was rubbed in contact with each other using the scratch method so that the isolates would coincide. Each petridish will be scratched with 2 and 4 different isolates. Combined etching between isolates forms the intersection line between isolates. Furthermore, all petridishes were incubated for 24 hours and observations were made 3 , 5 , and 7 days after inoculation. Isolates are said to be compatible if there is no zone of inhibition in the streak area of the two isolates.

The media used in the phosphate solubilizing bacteria bioassay experiment was carried out using Murphy media. The rice sprouts will be planted in a 100 $\mathrm{mL}$ test tube filled with $95 \mathrm{~mL}$ of liquid Murphy media and treated with $5 \mathrm{~mL}$ of phosphate solubilizing bacterial suspension (density $10^{7} \quad \mathrm{CFU} \quad \mathrm{mL}^{-1}$ ). Phosphatase activity was observed when the plants were 4 weeks after planting. Amount of Dissolved P, when the plants were 4 weeks after planting, using the Bray method.

\section{RESULTS AND DISCUSSCION \\ Compatibility of Phosphate Solubilizing Bacteria}

The compatibility test experiment between phosphate solubilizing bacterial isolates, each isolate did not show any inhibitory (Table-1). There were no inhibition zones between the tested isolates, thus the tested isolates showed synergistic interactions.

Table-1: Compatibility Test between Phosphate Solubilizing Bacteria

\begin{tabular}{|l|l|}
\hline Treatments & Results \\
\hline Burkholderia sp. x Pseudomonas mallei & Compatible \\
\hline Burkholderia sp. x Bacillus substilis & Compatible \\
\hline Burkholderia sp. x Bacillus megatherium & Compatible \\
\hline Pseudomonas mallei x Bacillus substilis & Compatible \\
\hline Pseudomonas mallei x Bacillus megatherium & Compatible \\
\hline Bacillus substilis x Bacillus megatherium & Compatible \\
\hline Burkholderia sp. x Pseudomonas mallei x Bacillus subtilis x Bacillus megatherium & Compatible \\
\hline
\end{tabular}

Compatibility between bacteria can be seen from the phosphate solubilizing bacterial isolates which are rubbed in contact with other isolates on NA media, where the scratches between bacteria are not interrupted (Figure-1). The compatibility or synergism of the two inoculated bacteria is a very important factor so that the two bacteria can function properly [11]. From the data in Table-1, it can be seen that the four isolates have compatible interactions with one another, so that the bacteria can be applied as a bio-fertilizer inoculant in the form of a consortium.

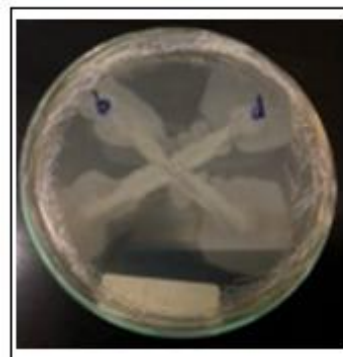

Streak 2 isolates

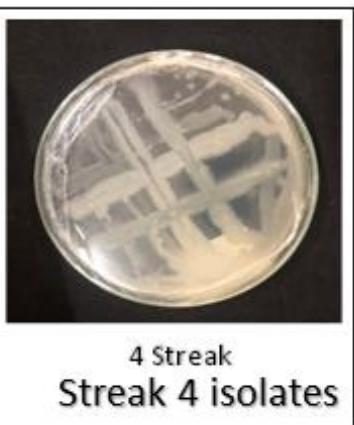

Streak 4 isolates
Fig-1: Compatibility test between isolates 


\section{Phosphatase Activity and P-Dissolved}

The ability of phosphate solubilizing bacteria to dissolve $\mathrm{P}$ elements that were not available for plants to become available for plants can be seen from the activity of phosphatase and P-dissolved enzymes. Based on the bioassay activities that have been carried out, the analysis of phosphatase and P-dissolved enzymes from phosphate solubilizing bacteria can be seen in Table- 2 .

Table-2: Phosphatase and P-dissolved from phosphate solubilizing bacteria

\begin{tabular}{|l|l|l|}
\hline Isolates & Phosphatase $(\boldsymbol{\mu g} \mathbf{~ p N P / g / h )}$ & P-dissolved $(\mathbf{p p m})$ \\
\hline Control & $4,21 \mathrm{a}$ & $870,79 \mathrm{a}$ \\
\hline Burkholderia sp. & $4,82 \mathrm{c}$ & $5307,63 \mathrm{~cd}$ \\
\hline Pseudomonas mallei & $4,53 \mathrm{~b}$ & $3909,55 \mathrm{~b}$ \\
\hline Bacillus substilis & $4,62 \mathrm{~b}$ & $4994,02 \mathrm{c}$ \\
\hline Bacillus megatherium & $4,56 \mathrm{~b}$ & $5625,44 \mathrm{de}$ \\
\hline Mixture of isolates & $4,83 \mathrm{c}$ & $6052,19 \mathrm{e}$ \\
\hline
\end{tabular}

Remarks: The average score followed by the same letter is not significantly different according to the Duncan Test at the $5 \%$ level

The results of the phosphatase enzyme produced by each bacteria are different. The isolate that produced the highest phosphatase enzyme was owned by the mixed of isolate $(4,83 \mu \mathrm{g} \mathrm{pNP} / \mathrm{g} / \mathrm{h})$, followed by the Burkholderia sp. $(4,82 \mu \mathrm{g} \mathrm{pNP/g} / \mathrm{h})$, Pseudomonas mallei produce phosphatase lower than another isolates $(4.53 \mu \mathrm{g} \mathrm{pNP} / \mathrm{g} \mathrm{h})$, and control treatment was lowest (4.21 $\mu \mathrm{g} \mathrm{pNP} / \mathrm{g} \mathrm{h})$.

Phosphatase enzyme is an enzyme that will be produced by phosphate solubilizing bacteria if the availability of phosphate is low [12]. Phosphatase enzymes will work by mineralizing organic $\mathrm{P}$ to inorganic $\mathrm{P}$ which can be absorbed by plants. The value of the resulting phosphatase enzyme activity is influenced by PSB which works actively in hydrolyzing organic P [9].

Based on the results of the P-dissolved test, the data obtained showed that each bacterial isolate had the ability to dissolve various $\mathrm{P}$ elements. The highest dissolved $\mathrm{P}$ value was owned by the mixed treatment isolate, which was $6052.19 \mathrm{ppm}$, followed by Bacillus megatherium at was $5625.44 \mathrm{ppm}$, then Burkholderia sp. was 5307.63 ppm, Bacillus substilis was 4994.02 ppm, and Pseudomonas mallei was 3909.55 ppm, and control treatment was $870.79 \mathrm{ppm}$. The activity of the phosphatase enzyme from each of these was one of the factors that influenced the variation in the dissolved $\mathrm{P}$ value produced by each isolate.

The results of the analysis of phosphatase and dissolved $\mathrm{P}$, it showed that isolates that have a high value of phosphatase enzymes will also produce high dissolved P-values. It can be seen that the highest value of the phosphatase enzyme is the mixed isolate, where the activity value of the phosphatase enzyme is 4,816 $\mu \mathrm{g} \mathrm{pNP} / \mathrm{g} / \mathrm{h}$ and has the highest P-dissolved yield of $6052.19 \mathrm{ppm}$. This is consistent with research conducted by Inge \& Padole [13] where the dissolution of $\mathrm{P}$ elements from organic compounds depends on the catalyst capacity of the phosphatase enzyme produced by the phosphate solubilizing bacteria.

\section{CONCLUSIONS}

Based on the results of the experiment on the compatibility test between the phosphate solubilizing bacterial isolates and the analysis of the activity of the phosphatase enzyme and the ability to dissolve the phosphate, it can be concluded that the compatibility test on the phosphate solubilizing bacterial isolates showed that each isolate was compatible. Furthermore, the result of experiment revealed that phosphate solubilizing bacteria could produce phosphatase enzyme ranges between 4,53-4,82 $\mu \mathrm{g} \mathrm{pNP} / \mathrm{g} / \mathrm{h}$ and $\mathrm{P}$ dissolved about 3909,55-6052,19 ppm. These phosphate solubilizing bacteria can be used as biofertilizers to increase soil $\mathrm{P}$ solubility.

\section{ACKNOWLEDGMENTS}

Part of this work was carried out within the financial support from the Directorate General of Higher Education Ministry of Research and Technology Indonesia (Applied Research: 1827/UN6.3.1/LT/2020). The authors would like to thank staff Laboratory of Soil Biology Faculty of Agriculture, Universitas Padjadjaran for their cooperation.

\section{REFERENCES}

1. Whitelaw, M. A. (1999). Growth promotion of plants inoculated with phosphate-solubilizing fungi. In Advances in agronomy (Vol. 69, pp. 99151). Academic Press.

2. Khan, A. A., Jilani, G., Akhtar, M. S., Naqvi, S. M. S., \& Rasheed, M. (2009). Phosphorus solubilizing bacteria: occurrence, mechanisms and their role in crop production. J agric biol sci, 1(1), 48-58.

3. Adeleke, R., Nwangburuka, C., \& Oboirien, B. (2017). Origins, roles and fate of organic acids in soils: A review. South African Journal of Botany, 108, 393-406.

4. Fitriatin, B. N., Fauziah, D., Fitriani, F. N., Ningtyas, D. N., Suryatmana, P., Hindersah, R., ... \& Simarmata, T. (2020). Biochemical activity and bioassay on maize seedling of selected indigenous phosphate-solubilizing bacteria isolated from the 
acid soil ecosystem. Open Agriculture, 5(1), 300304.

5. Kalayu, G. (2019). Phosphate solubilizing microorganisms: promising approach as biofertilizers. International Journal of Agronomy, 2019.

6. Pande, A., Pandey, P., Mehra, S., Singh, M., \& Kaushik, S. (2017). Phenotypic and genotypic characterization of phosphate solubilizing bacteria and their efficiency on the growth of maize. Journal of Genetic Engineering and Biotechnology, 15(2), 379-391.

7. Yadav, H., Fatima, R., Sharma, A., \& Mathur, S. (2017). Enhancement of applicability of rock phosphate in alkaline soils by organic compost. Applied Soil Ecology, 113, 80-85.

8. Richardson, A. E., \& Hadobas, P. A. (1997). Soil isolates of Pseudomonas spp. that utilize inositol phosphates. Canadian Journal

of Microbiology, 43(6), 509-516.
9. Alori, E. T., Glick, B. R., \& Babalola, O. O. (2017). Microbial phosphorus solubilization and its potential for use in sustainable agriculture. Frontiers in microbiology, 8, 971:1-8

10. Deng, Y. J., \& Wang, S. Y. (2016). Synergistic growth in bacteria depends on substrate complexity. Journal of Microbiology, 54(1), 23 30 .

11. Molina-Romero, D., Baez, A., QuinteroHernández, V., Castañeda-Lucio, M., FuentesRamírez, L. E., Bustillos-Cristales, M. D. R., ... \& Muñoz-Rojas, J. (2017). Compatible bacterial mixture, tolerant to desiccation, improves maize plant growth. PloS one, 12(11), e0187913.

12. Joner, E. J., Van Aarle, I. M., \& Vosatka, M. (2000). Phosphatase activity of extra-radical arbuscular mycorrhizal hyphae: a review. Plant and Soil, 226(2), 199-210.

13. Ingle, K. P., \& Padole, D. A. (2017). Phosphate solubilizing microbes: An overview. Int. J. Curr. Microbiol. App. Sci, 6(1), 844-852. 